\title{
Mixing ratio of zinc nitrate and phosphoric acid for preparation of zinc phosphate white pigments
}

\author{
(Mistura de nitrato de zinco e ácido fosfórico para preparação de \\ pigmentos brancos de fosfato de zinco)
}

\author{
H. Onoda*, M. Haruki \\ Department of Informatics and Environmental Sciences, Kyoto Prefectural University, 1-5, Shimogamo \\ Nakaragi-cyo, Sakyo-ku, Kyoto 606-8522, Japan
}

\begin{abstract}
In this work, zinc phosphates were prepared from zinc nitrate and phosphoric acid at various $\mathrm{Zn} / \mathrm{P}$ ratios as a novel white pigment for use in cosmetics. The chemical composition, powder properties, photocatalytic activity, color phase, moisture retention, and smoothness of the zinc phosphates were studied. Samples prepared at $\mathrm{Zn} / \mathrm{P}=2 / 1,3 / 2$, and $1 / 1$ indicated XRD pattern of $\mathrm{Zn}_{3}\left(\mathrm{PO}_{4}\right)_{2} \bullet 4 \mathrm{H}_{2} \mathrm{O}$. The plane particles were observed in SEM images of sample prepared at $\mathrm{Zn} / \mathrm{P}=2 / 1,3 / 2$ and $1 / 1$. The photocatalytic activity of these zinc phosphate particles was too less to protect the sebum on the skin. The materials prepared at $\mathrm{Zn} / \mathrm{P}=2 / 1,3 / 2$ and $1 / 1$ and their thermal products at $100{ }^{\circ} \mathrm{C}$ showed a high reflectance within the range of visible light. Samples prepared at high $\mathrm{Zn} / \mathrm{P}$ ratio indicated small MIU value.
\end{abstract}

Keywords: white pigment, zinc phosphates, $\mathrm{Zn} / \mathrm{P}$ ratio, photocatalytic activity, particle shape.

Resumo

Neste trabalho, os fosfatos de zinco foram preparados a partir de nitrato de zinco e ácido fosfórico variando Zn/P como um novo pigmento branco para utilização em cosméticos. A composição química, propriedades dos pós, atividade fotocatalítica, cor, humidade e textura dos fosfatos de zinco foram estudadas. Amostras preparadas de Zn/P = 2/1, 3/2, e 1/1 indicaram DRX de $\mathrm{Zn}_{3}\left(\mathrm{PO}_{4}\right)_{2} \cdot 4 \mathrm{H}_{2} \mathrm{O}$. As partículas foram observadas por imagens de $\mathrm{MEV}$ das amostras preparadas de $\mathrm{Zn} / \mathrm{P}=2 / 1,3 / 2$ e 1/1. A atividade fotocatalítica destas partículas de fosfato de zinco foi muito menor para proteger o sebo da pele. Os materiais preparados de $\mathrm{Zn} / \mathrm{P}=2 / 1,3 / 2$ e $1 / 1$ e os seus produtos térmicos a $100{ }^{\circ} \mathrm{C}$ mostrou uma alta reflectância na faixa da luz visivel. Amostras preparadas em alta proporção de $\mathrm{Zn} / \mathrm{P}$ indicaram pequeno valor $\mathrm{MIU}$.

Palavras-chave: pigmento branco, fosfatos de zinco, proporção $\mathrm{Zn} / \mathrm{P}$, atividade catalítica, forma da partícula.

\section{INTRODUCTION}

As white pigments, titanium dioxide and zinc oxide are used for cosmetic applications [1]. These oxides are well known to exhibit photocatalytic activity. Therefore, a certain amount of sebum on the skin is decomposed by the ultraviolet radiation in sunlight. To repress this effect, several kinds of technical processes have been investigated and used. In one such technique, composite particles with silicon oxide were utilized [2]. However, such particle materials are too hard for use on the human face. Instead, soft materials are required for use as a white facial pigment. In addition, one report stated that microfine oxide is absorbed through the skin [3]. Therefore, a novel white pigment that is not absorbed must be used.

Phosphates have been used as ceramic materials, catalysts, fluorescent materials, dielectric substances, metal-surface treatments, detergents, food additives, fuel cells, pigments, and so on $[4,5]$. Phosphate materials are well known to have a high affinity for living organisms and are therefore expected to be useful as white pigments in cosmetics.

When used as a cosmetic pigment, the particle shape and size distribution of the phosphate are important. Spherical homogenized particles are expected to spread well on the skin. However, overly small particles are unsuitable because the pigments might enter the pores of the skin. Generally, the pigments with sub-micrometer size are used. In earlier studies [6-8], we prepared titanium and zinc phosphate pigments with no catalytic activity. The ratio of cation / phosphorus is important factor on the powder properties of phosphate materials [9]. Therefore, the present work was undertaken to obtain homogenized zinc phosphate particles by changing the mixing ratio of raw materials.

For this work, as a novel white pigment, zinc phosphate, was prepared from zinc nitrate and phosphoric acid at various $\mathrm{Zn} / \mathrm{P}$ ratios. Their respective chemical compositions, powder properties, photocatalytic activity, color phases, moisture retention, smoothness of the 
obtained precipitates, and thermal products were studied for application in cosmetics.

\section{EXPERIMENTAL}

$0.1 \mathrm{~mol} / \mathrm{L}$ of a zinc nitrate solution was mixed with $0.1 \mathrm{~mol} / \mathrm{L}$ of a phosphoric acid solution in molar ratios of $\mathrm{Zn} / \mathrm{P}=2 / 1,3 / 2,1 / 1$, and $2 / 3$ at room temperature for more than $1 \mathrm{~h}$. The precipitates were then filtered off, washed with water, and dried at room temperature over 3 days. All chemicals were of commercial purity from Wako Chemical Industries Ltd. (Osaka Japan) and used without further purification.

A part of the precipitates was dissolved in a hydrochloric acid solution. The ratios of phosphorus and zinc in the precipitates were also calculated based on the ICP results of these solutions using an SPS1500VR from Seiko Instruments, Inc. The chemical compositions of these materials were analyzed using X-ray diffraction (XRD). The XRD patterns were recorded on an X-ray diffractometer (MiniFlex; Rigaku Corp.) using monochromated Cuka radiation. The samples were heated at $100{ }^{\circ} \mathrm{C}$ in air to remove the adsorbed water, and the thermal products were analyzed according to their XRD patterns.

The particle shapes and sizes of the precipitates, as well as their thermal products at $100{ }^{\circ} \mathrm{C}$, were estimated based on scanning electron microscopy (SEM) images and particle size distributions. The SEM images of the zinc phosphates were observed (JGM-5510LV; JEOL). The particle size distributions of these materials were measured using a centrifugal precipitation particle-size distribution (SA-CP3L, Shimadzu Corp.).

The cosmetic properties were estimated according to the photocatalytic activity, color phase, moisture retention, and smoothness. The photocatalytic activity of the samples was estimated through the decomposition of methylene blue using $365 \mathrm{~nm}$ radiation (sample; $0.01 \mathrm{~g}$, methylene blue; $1 \times 10^{-5} \mathrm{~mol} / \mathrm{L}, 4 \mathrm{~mL}$ ) $[10,11]$. The residual ratio of methylene blue was calculated from the absorption at $660 \mathrm{~nm}$ with a UV2100, Shimadzu Co. The color of the phosphate pigments was estimated using ultraviolet-visible (UV-Vis) reflectance spectra from a UV2100, Shimadzu Co. For the moisture retention of the samples, $0.3 \mathrm{~g}$ per sample was mixed with $0.1 \mathrm{~g}$ of water, and the weight loss was then evaluated at $50{ }^{\circ} \mathrm{C}$ (MS-70 Moisture Analyzer, A and D Instruments Co. Ltd.). The same weight loss over longer time meant high water retention of samples. The particle smoothness was measured on artificial leather based on a KES-SE objective evaluation of the surface friction property (Kato Tech Co., Ltd.). The MIU and MMD values represent the slipping resistance and roughness of the powders, respectively. The sample powders were spread onto the leather, and a sensor was then run over the powders (scan speed; $1 \mathrm{~mm} / \mathrm{sec}$, area scanned; $3 \mathrm{~cm}$ ). The values of MIU and MMD were calculated respectively from the power to move a sensor and the pitching of a sensor. The values of MIU and MMD have no unit because these values are related with coefficient of friction and scattering, respectively.

\section{RESULTS AND DISCUSSION}

\section{Chemical composition and powder properties of zinc phosphates}

Table I shows the $\mathrm{Zn} / \mathrm{P}$ ratios of the samples prepared under various conditions. Sample prepared at $\mathrm{Zn} / \mathrm{P}=$ 2/1 had high $\mathrm{Zn} / \mathrm{P}$ ratio (1.63), on the other hand, sample prepared at $Z n / P=2 / 3$ indicated low $Z n / P$ ratio (1.18). Other samples had about a $1.5 \mathrm{Zn} / \mathrm{P}$ ratio, which corresponds to a composition of $\mathrm{Zn}_{3}\left(\mathrm{PO}_{4}\right)_{2}$. The $\mathrm{Zn} / \mathrm{P}$ ratios in precipitates of the former samples were between $\mathrm{Zn} / \mathrm{P}$ ratio in preparation and 1.5. Zinc phosphate, $\mathrm{Zn}_{3}\left(\mathrm{PO}_{4}\right)_{2}$, was easy to form in these conditions.

Table I - Zn/P ratios of precipitates prepared under various $\mathrm{Zn} / \mathrm{P}$ ratios.

[Tabela I - Preparação de precipitados de Zn/P em várias proporções de Zn/P.]

\begin{tabular}{ccc}
\hline sample & $\begin{array}{c}\text { Zn/P ratio in } \\
\text { preparation }\end{array}$ & $\begin{array}{c}\mathrm{Zn} / \mathrm{P} \text { ratio in } \\
\text { precipitates }\end{array}$ \\
\hline $\mathrm{A}$ & $2 / 1$ & 1.63 \\
$\mathrm{~B}$ & $3 / 2$ & 1.51 \\
$\mathrm{C}$ & $1 / 1$ & 1.50 \\
$\mathrm{D}$ & $2 / 3$ & 1.18 \\
\hline
\end{tabular}

Fig. 1 shows the XRD patterns of the samples prepared under various conditions (without heating). Samples prepared at $\mathrm{Zn} / \mathrm{P}=2 / 1,3 / 2$, and $1 / 1$ indicated XRD pattern of $\mathrm{Zn}_{3}\left(\mathrm{PO}_{4}\right)_{2} \cdot 4 \mathrm{H}_{2} \mathrm{O}$ (Fig. 1(a)(b)(c)) [12]. Because unknown peaks were observed in XRD pattern of sample prepared at $\mathrm{Zn} / \mathrm{P}=2 / 3$, this material was the mixture of $\mathrm{Zn}_{3}\left(\mathrm{PO}_{4}\right)_{2} \bullet 4 \mathrm{H}_{2} \mathrm{O}$ and other compounds (Fig. 1(d)). This ratio, $\mathrm{Zn} / \mathrm{P}=2 / 3$, was too different with the $\mathrm{Zn} / \mathrm{P}$ ratio in $\mathrm{Zn}_{3}\left(\mathrm{PO}_{4}\right)_{2} \bullet 4 \mathrm{H}_{2} \mathrm{O}$ to form other compounds. The peak intensity was also affected from the preparation condition. Since samples prepared at $\mathrm{Zn} / \mathrm{P}=$ $1 / 1$ had strong peaks, the crystal structure was easy to grow in samples prepared at $\mathrm{Zn} / \mathrm{P}=1 / 1$.

In terms of particle shape, spherical particles are suitable for cosmetic applications. Fig. 2 shows SEM images of the samples prepared under various conditions. The plane parts on particles were observed in samples prepared at $\mathrm{Zn} / \mathrm{P}=$ 2/1, 3/2, and 1/1 (Fig. 2(a)(b)(c)). On the other hand, no specified shape was observed in sample prepared at $\mathrm{Zn} / \mathrm{P}$ $=2 / 3$ (Fig. 2(d)). The plate particles were related with the formation of $\mathrm{Zn}_{3}\left(\mathrm{PO}_{4}\right)_{2} \cdot 4 \mathrm{H}_{2} \mathrm{O}$. Fig. 3 shows the particle size distribution of the samples prepared under various conditions. Sample prepared at $\mathrm{Zn} / \mathrm{P}=3 / 2$ indicated high ratio of particles at 1.5 and $15 \mu \mathrm{m}$, other samples indicated high ratio at $15 \mu \mathrm{m}$. When the particles were aggregated, samples indicated smaller particle size in these distributions, because samples were dispersed and stirred in solution before the measurement of the particle size distribution. Since these 


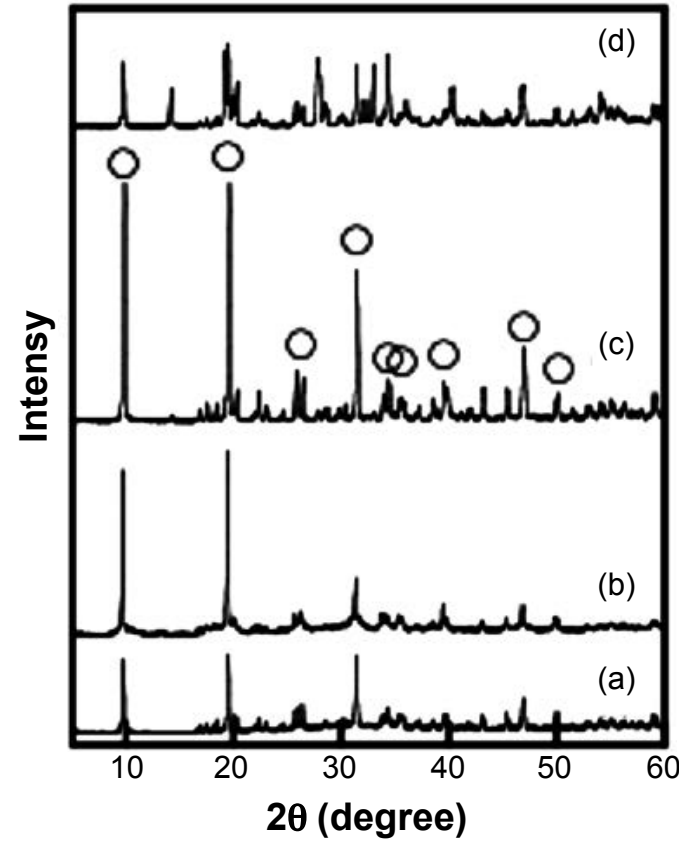

Figure 1: XRD patterns of samples prepared under various $\mathrm{Zn} / \mathrm{P}$ ratio: (a) $\mathrm{Zn} / \mathrm{P}=2 / 1$, (b) $3 / 2$, (c) $1 / 1$, and (d) $2 / 3$, ०; $\mathrm{Zn}_{3}\left(\mathrm{PO}_{4}\right)_{2} \bullet 4 \mathrm{H}_{2} \mathrm{O}$. [Figura 1: Difratogramas de raios $X$ das amostras preparadas de $\mathrm{Zn} / \mathrm{P}$ : (a) $\mathrm{Zn} / \mathrm{P}=2 / 1$, (b) $3 / 2$, (c) $1 / 1$, e (d) $2 / 3$, o; $\mathrm{Zn}_{3}\left(\mathrm{PO}_{4}\right)_{2} \cdot 4 \mathrm{H}_{2} \mathrm{O} . \mathrm{J}$
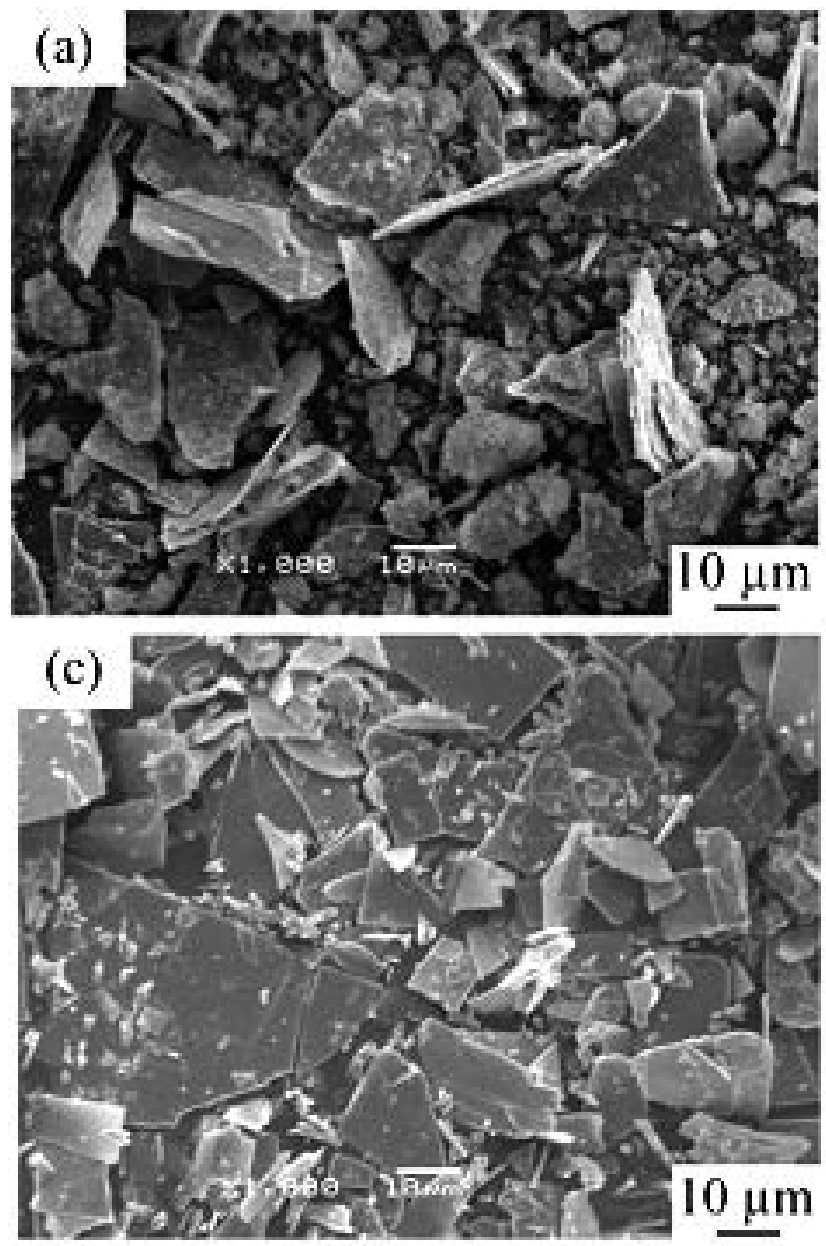

results in particle size distributions were corresponding with the above particle size in SEM images, the phosphate particles were considered to be not an aggregate.

Small and homogeneous particles are suitable for cosmetic applications. However, overly small particles have a major shortcoming in that they enter the pores of the skin [3]. Generally, the pigments with sub-micrometer size are used. The standard size of white pigment particles used in cosmetics is difficult to determine because the pore sizes of the skin are affected by such factors as age, gender, and climate. Furthermore, overly large particles are inappropriate owing to a cracking of their coating on the skin. It is therefore important to control the particle sizes of the pigment.

\section{Cosmetic properties of zinc phosphates}

Fig. 4 shows the respective photocatalytic activities of the samples prepared under various conditions. Because zinc oxide is used as a white pigment in cosmetics, the compound was evaluated for a comparison with zinc phosphate [1]. Methylene blue decomposed with zinc oxide under UV irradiation (Fig. 4(e)). On the other hand, zinc phosphate, which is a mild material that can protect the
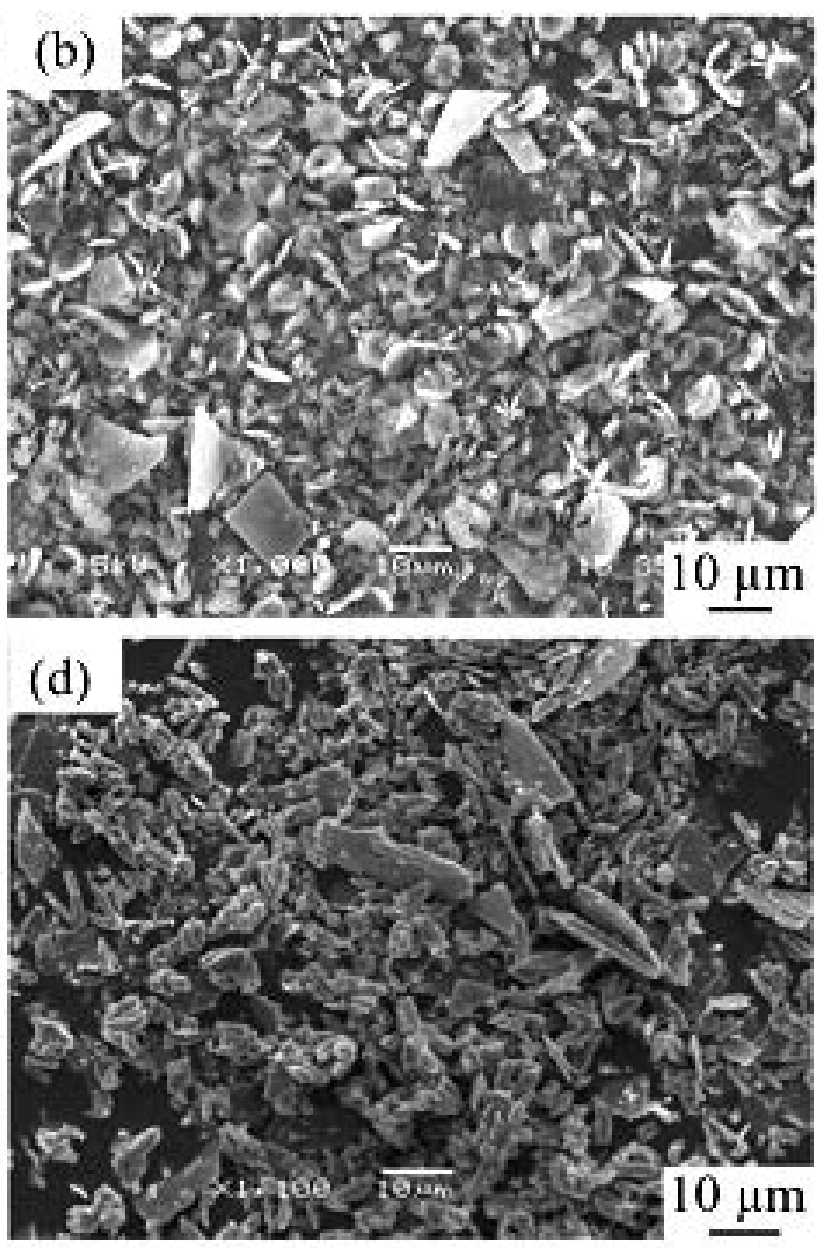

Figure 2: SEM images of samples prepared under various $\mathrm{Zn} / \mathrm{P}$ ratios: (a) $\mathrm{Zn} / \mathrm{P}=2 / 1$, (b) 3/2, (c) 1/1, and (d) $2 / 3$.

[Figura 2: Imagens de MEV das amostras preparadas $Z n / P$ : (a) $Z n / P=2 / 1$, (b) $3 / 2$, (c) $1 / 1$, e (d) 2/3.] 


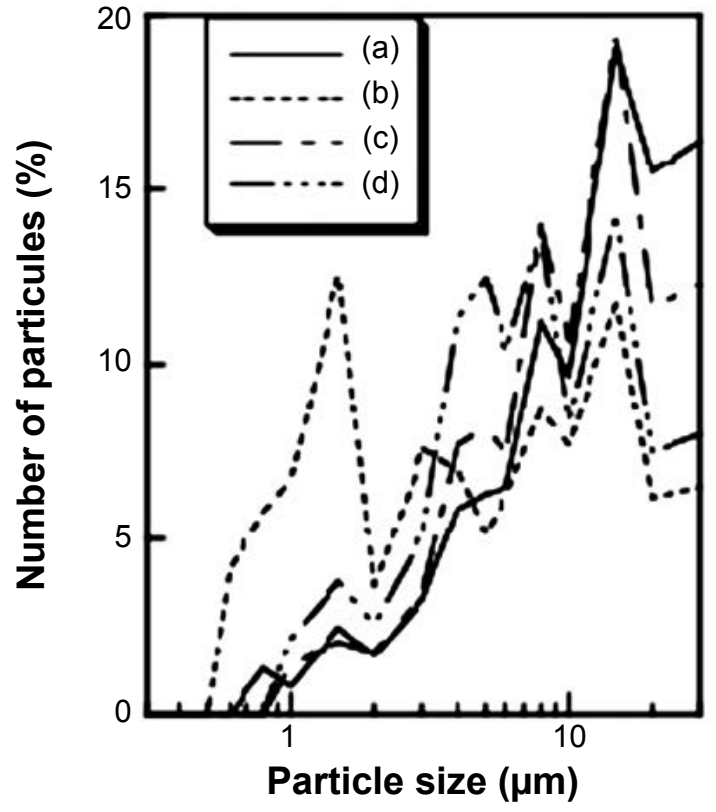

Figure 3: Particle size distribution of samples prepared under various $\mathrm{Zn} / \mathrm{P}$ ratios: (a) $\mathrm{Zn} / \mathrm{P}=2 / 1$, (b) $3 / 2$, (c) $1 / 1$, and (d) $2 / 3$. [Figura 3: Distribuição de tamanho das partículas das amostras preparadas $\mathrm{Zn} / \mathrm{P}$ : (a) $\mathrm{Zn} / \mathrm{P}=2 / 1$, (b) $3 / 2$, (c) $1 / 1$, e (d) 2/3.]

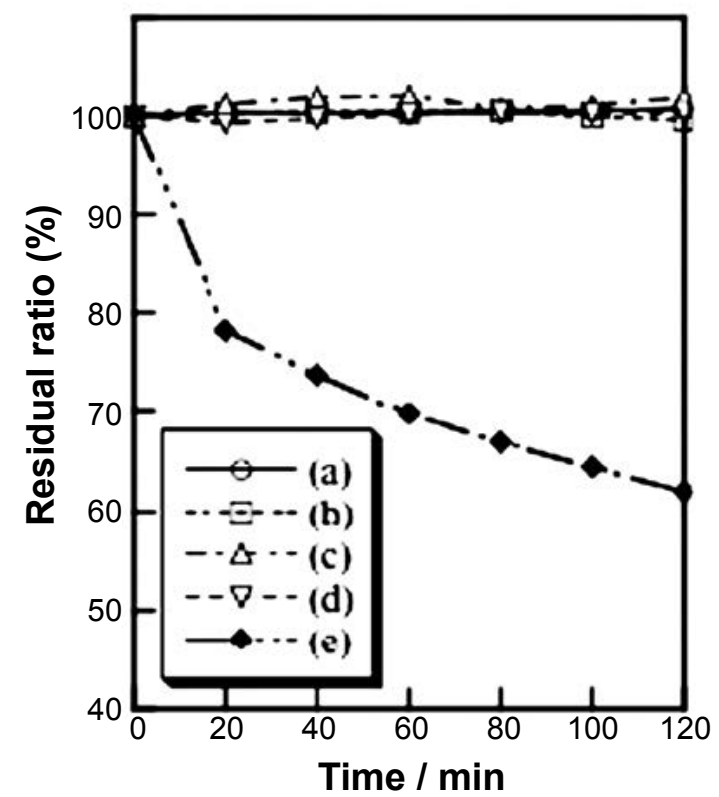

Figure 4: Photocatalytic activity of samples prepared under various $\mathrm{Zn} / \mathrm{P}$ ratios: (a) blank, (b) $\mathrm{Zn} / \mathrm{P}=2 / 1$, (c) 3/2, (d) 1/1, and (e) $\mathrm{ZnO}$. [Figura 4: Atividade fotocatalitica das amostras preparadas $\mathrm{Zn} / \mathrm{P}$ : (a) blank, (b) $Z n / P=2 / 1$, (c) 3/2, (d) $1 / 1$, e (e) $Z n O$.

sebum on the skin, had little photocatalytic activity (Fig. 4(b)-4(d)). Because sample prepared at $\mathrm{Zn} / \mathrm{P}=2 / 3$ was easy to form the aggregations, the photocatalytic activity of this sample was difficult to be estimated. Fig. 5 shows the UV-Vis reflectance spectra of the zinc phosphates prepared under various conditions. Samples prepared at $\mathrm{Zn} / \mathrm{P}=2 / 1$, $3 / 2$, and $1 / 1$ showed a high reflectance within the range of visible light (Fig. 5(a)(b)(c)). Sample prepared at $\mathrm{Zn} / \mathrm{P}=2 / 3$ shows lower reflectance than other samples. Samples heated at $100{ }^{\circ} \mathrm{C}$ had a high reflectance in spite of the $\mathrm{Zn} / \mathrm{P}$ ratio in preparation (not shown). When sample prepared at $\mathrm{Zn} / \mathrm{P}=$ $2 / 3$ lost the adsorbed water by heating, the sample heated at $100{ }^{\circ} \mathrm{C}$ indicated high reflectance.

Moisture helps to prevent the itchiness and damage to the skin. It is important that the pigments for use in cosmetics retain the moisture on the skin [11]. Fig. 6 shows the moisture retention of the samples prepared under various conditions. At the same retention time, a small weight loss indicates the high moisture retention of the phosphate pigments. For example, at $5 \mathrm{~min}$, sample prepared at $\mathrm{Zn} / \mathrm{P}=2 / 1$ indicated $22.3 \%$ of weight loss (Fig. 6(a)), on the other hand, sample

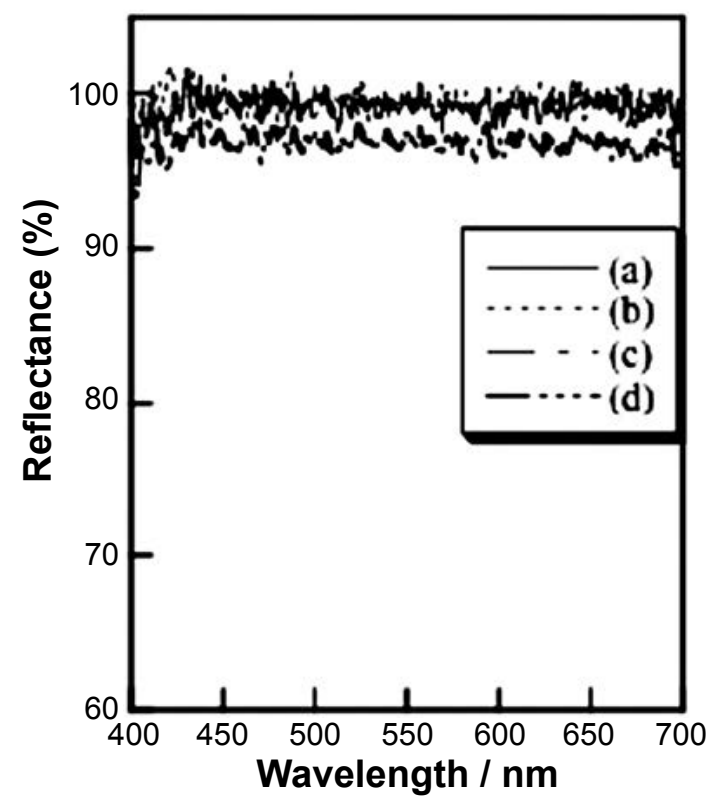

Figure 5: UV-Vis reflectance of samples prepared under various $\mathrm{Zn} / \mathrm{P}$ ratios: (a) $\mathrm{Zn} / \mathrm{P}=2 / 1$, (b) $3 / 2$, (c) $1 / 1$, and (d) $2 / 3$.

[Figura 5: Refletância UV-Vis das amostras preparadas $\mathrm{Zn} / \mathrm{P}$ : (a) $\mathrm{Zn} / \mathrm{P}=2 / 1$, (b) $3 / 2$, (c) $1 / 1$, e (d) $2 / 3$.]

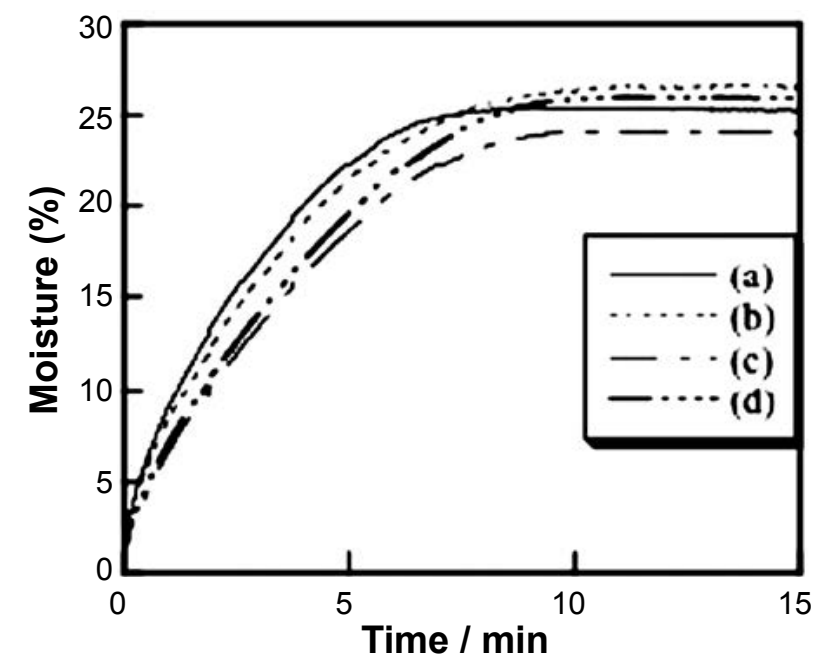

Figure 6: Water retention of samples prepared under various $\mathrm{Zn} / \mathrm{P}$ ratios: (a) $\mathrm{Zn} / \mathrm{P}=2 / 1$, (b) $3 / 2$, (c) $1 / 1$, and (d) $2 / 3$.

[Figura 6: Retenção de água das amostras preparadas $\mathrm{Zn} / \mathrm{P}$ : (a) $\mathrm{Zn} / \mathrm{P}=2 / 1$, (b) $3 / 2$, (c) $1 / 1$, e (d) $2 / 3$.] 
Table II - Smoothness of samples prepared under various $\mathrm{Zn} / \mathrm{P}$ ratios.

[Tabela II - Textura das amostras preparadas em várias proporções de $\mathrm{Zn} / \mathrm{P}$.]

\begin{tabular}{cccc}
\hline sample & $\begin{array}{c}\text { Zn/P ratio in } \\
\text { preparation }\end{array}$ & MIU & MMD \\
\hline $\mathrm{A}$ & $2 / 1$ & 0.356 & 0.006 \\
$\mathrm{~B}$ & $3 / 2$ & 0.586 & 0.016 \\
$\mathrm{C}$ & $1 / 1$ & 0.623 & 0.008 \\
$\mathrm{D}$ & $2 / 3$ & - & - \\
\hline
\end{tabular}

prepared at $\mathrm{Zn} / \mathrm{P}=1 / 1$ indicated $18.7 \%$ of weight loss (Fig. $6(\mathrm{c})$ ). The samples prepared at $\mathrm{Zn} / \mathrm{P}=1 / 1$ had a higher water retention than other samples.

As described above, a pigment with a high level of smoothness spreads well across the skin, and powder smoothness is also important for use in cosmetics [13]. Table II shows the smoothness of the samples prepared under various conditions. Because sample prepared at $\mathrm{Zn} / \mathrm{P}$ $=2 / 3$ was easy to form the aggregations, the MIU and MMD values of this sample could not be measured. Generally, for a cosmetic application, the suitable MIU and MMD values are smaller than 0.6 and smaller than 0.04 , respectively. Samples prepared at high $\mathrm{Zn} / \mathrm{P}$ ratio indicated small MIU value.

\section{CONCLUSION}

Zinc phosphates were obtained from zinc nitrate and phosphoric acid solution at various $\mathrm{Zn} / \mathrm{P}$ ratios. Samples prepared at $\mathrm{Zn} / \mathrm{P}=2 / 1,3 / 2$, and $1 / 1$ indicated $\mathrm{XRD}$ pattern of $\mathrm{Zn}_{3}\left(\mathrm{PO}_{4}\right)_{2} \cdot 4 \mathrm{H}_{2} \mathrm{O}$. The XRD peak intensity was varied from $\mathrm{Zn} / \mathrm{P}$ ratio under preparation condition. The plane particles were observed in SEM images of samples prepared at $\mathrm{Zn} / \mathrm{P}$ $=2 / 1,3 / 2$ and $1 / 1$. The obtained zinc phosphates exhibit less photocatalytic activity, thereby protecting the sebum on the skin. The materials prepared at $\mathrm{Zn} / \mathrm{P}=2 / 1,3 / 2$ and $1 / 1$ and their thermal products at $100{ }^{\circ} \mathrm{C}$ showed a high reflectance within the range of visible light. Samples prepared at high $\mathrm{Zn} / \mathrm{P}$ ratio indicated small MIU value. The mixing ratio of zinc nitrate and phosphoric acid is important factor for preparation of zinc phosphate white pigments.

\section{ACKNOWLEDGEMENT}

The authors are grateful to Dr. Takeshi Toyama, Nihon University, Japan, for smoothness measurements.

\section{REFERENCES}

[1] U. Diebold, Surface Sci. Report 48, 5-8 (2003) 53.

[2] M. Senzuki, T. Tamura, K. Miura, Y. Ikarashi, Y. Watanabe, M. Fujii, J. Toxi. Sci. 35, 1 (2010) 107.

[3] A. O. Gamer, E. Leibold, B. Van Ravenzwaay, Toxi. Vitro 20, 3 (2006) 301.

[4] D. J. Jones, G. Aptel, M. Brandhorst, M. Jacquin, J. Jimenez-Jimenez, A. Jimenez-Lopez, P. Maireles-Torres, I. Piwonski, E. Rodrigues-Castellon, J. Zajac, J. Roziere, J. Mater. Chem. 10, 8 (2000) 1957.

[5] A. Bhamik, S. Inagaki, J. Am. Chem. Soc. 123, 4 (2001) 691.

[6] H. Onoda, T. Yamaguchi, J. Mater. Chem. 22, 37 (2012) 19826.

[7] H. Onoda, T. Yamaguchi, A. Takenaka, Int. J. Cosm. Sci. 34, 1 (2012) 86.

[8] H. Onoda, M. Haruki, T. Toyama, Ceram. Int. 40, 2 (2014) 3433.

[9] S. Raynaud, E. Champion, D. Bernache-Assollant, Biomater. 23, 4 (2002) 1065.

[10] V. Ramaswamy, N. B. Jagtap, S. Vijayanand, D. S. Bhange, P. S. Awati, Mater. Res. Bull. 43, 5 (2008) 1145.

[11] P. Du, A. Bueno-Lopez, M. Verbaas, A. R. Almeida, M. Makkee, J. A. Moulijn, G. Mui, J. Catal. 260, 1 (2008) 75.

[12] A. Whitaker, Acta Cryst. B 31 (1975) 2026.

[13] S. Y. Cheng, C. W. M. Yuen, C. W. Kan, K. K. L. Cheuk, J. C. O. Tang, S. Y. Li, Fib. Polym. 10, 1 ( 2009) 132.

(Rec. 28/02/2014, Ac. 21/04/14) 